\title{
Design and Research on Platform to Enhance College Students' Art Appreciation Capability Based on Modern Information Technology
}

\author{
Xifei Shen, and Yi Wang \\ Huazhong Agricultural University, 430070 Wuhan Hubei, China
}

\begin{abstract}
Nowadays, with the rapid development of modern information technology, the college students could not preferably choose and learn to enhance their own art appreciation capability. Therefore, the colleges and universities have a more urgent desire to organize, develop and provide a good platform to enhance the college students' art appreciation capability based on modern information technology. This paper describes how to enhance the art appreciation capability in detail, and designs and analyzes the platform to enhance college students' art appreciation capability based on modern information technology---the "Music Corner" and the "Dance Corner", indicating that the exchange platform built with modern information technology can promotes the college students' art appreciation capability. Finally, through the analysis of statistical results of the questionnaire, college students are fonder of art appreciation after the establishment of platform, more inclined to the comprehensive learning of art, more brave to express their own sense of art, and fonder of artistic creation.
\end{abstract}

Keywords. modern information technology; art appreciation capability; questionnaire

\section{Introduction}

Nowadays, in order to improve a certain ability of college students, many colleges and universities set up a certain activity area on the official website of their own school for students to exchange and improve their ability. Most of activity areas are "English corner" and so on. Through setting up the activity area, the college students can be more convenient to exchange and learn through the modern information technology platform of the school's official website, so that the colleges and universities can obtain a good effect of these activity areas.

The art appreciation capability refers to the physical and mental characteristics that people are congenital to possess or obtained from acquired learning, experience and summary. The development of art appreciation capability is mostly relying on acquired learning, while congenial factors just have slim impact on it. The research of specialists and scholars 
in the educational cycle indicates that in the aspect of expression level and communicative competence, children who learn more about art perform better than those who learn less. The research results indicate well that a better art environment is very important for a person's growth. Nowadays, with the rapid development of modern information technology, the college students could not preferably choose and learn to enhance their own art appreciation capability. Therefore, the colleges and universities have a more urgent desire to organize, develop and provide a good platform to enhance the college students' art appreciation capability based on modern information technology.

\section{How to enhance art appreciation capability}

\subsection{Improve the knowledge about the objectiveness of aesthetic value}

The aesthetics of art which is established based on the value of life practice is of great objectivity. In the entire process of appreciation and evaluation, due to the differences in the culture of regions and ethnics and the ways of life and production, the values will be different and the principle of values will be different as well, but it will not affect the appreciation of art objectiveness. The value of one thing is not always equivalent to people's evaluation. Different people have different evaluation methods, so the value and the evaluation are also in the unity of opposites. An important factor for both opposites is the background knowledge and thinking habit of human beings. In the process of appreciation of everything, as the differences in the subject of appreciation, there will be different appreciation results. For example, when a person is sad, no matter how cheerful the outside atmosphere is, it could not change the feeling of his/her sadness. In contrast, when a person is happy, no matter how tough the environment is, it could not easily let his/her get sad. The differences in culture and customs bring greater differences in the appreciation result, so it is very difficult for a China's painting to be favored by European and American people. Therefore, the extent of consistency between appreciation of the comment of subject and objectivity of things depends on whether the habit of appreciation of subject is consistent with the nature of the subject appreciated. A person who is unable to translate ancient Chinese prose will fail to appreciate a variety of hints and beauty brought by the ancient characters to the people in today's society. In the process of appreciation, there is not only a need to appreciate the subject, but also a need to upgrade the external manifestations of art to the understanding of inherent emotional expression with a spirit of rational thought. A person who is able to find the beauty and appreciate the beauty can feel any aesthetic atmosphere, and further upgrades the most common time to experience the aesthetic point of view. Thus increasing the appreciation and evaluation capability to appreciate the subject and remove nonaesthetic information of the things is a good way to improve the cognition of aesthetic value of object objectivity.

\subsection{Grasp content and form of artistic work}

We can generally understand through this method. The artistic work which can be repeatedly reproduced gives priority to express its profound content, while the artistic work which is only with external manifestation gives priority to express its pattern of manifestation. Both of them have a certain degree of reproduction and representation though both of focus is different. The dominance and recessiveness of both reproduction and representation content is contrary. The reproduction content of the former one is in a prominent place, while the representation content of the latter one is in a prominent place. Similarly, the recessive trait represented is also contrary. The understanding and analysis of the things are superior to its 
intuition, because the intuition is a kind of dynamic understanding of things, and analysis can be stationary to a certain aspect, but understanding is linked together with the physical intuition and analysis. We must rely on pure intuition, and then conduct a further all-around analysis, so as to analyze the static beauty from a dynamic perspective. In another part, the intuition is a crucial part of the analysis. Without things that can be felt by intuition, there are not deep analysis results. This series of process is a process to guide us to find the essence of things. Similarly, after analysis, there is still a cyclic process of exploration and reanalysis simply relying on the intuition. This is also a process of changing people's knowledge from perceptual level to rational level. In the entire process of art appreciation, the important indicators that are to determine whether the appreciation of artistic work is accurate are intuitive feelings on the artistic work, analysis of the author's background and personality, and in-depth perception of the pattern of manifestation of artistic work, and they are also key points to enhance the appreciation level of appreciation subjects. However, if the goal is to enhance the art appreciation capability, the contemporary college students not only need to have an intuitive understanding and feeling of arts itself and the corresponding characteristics of form and style, but also need to constantly learn relevant historical and cultural theory, and to be equipped with a certain interest. Of course, these are inseparable from the appropriate platforms provided by the colleges and universities. The colleges and universities should provide a platform for the college students to enhance their own quality, appreciate art with an optimistic attitude and enhance the college students' value and capability to appreciate art.

\subsection{Encourage to appreciate art with an approach of association}

Association is a phenomenon of mental activity to imagine other things due to something, so as to further form a different state in the brain. In this case, the thought in human's mind will have a new combination and form a brand new loss. This is a process for human beings to imagine. Art comes from imagination, that is, the production of artistic work is inseparable from the imagination of things. In the entire process of appreciation, direct feelings of people given by the art make people combine with their own experience, naturally arouse their own imagination and understanding of the artistic work. It may be the same with the work, or imagine an object that is very different from the work, which is a process of recreation of the human brain. The association and imagination is based on person's cultural background. In other words, the more things a person experiences, the higher cultural quality is, and the stronger imagination sentiment on the art is. Therefore, as long as college students have more sentiment in daily life and learn more social experience, the power of imagination and art appreciation capability will be correspondingly enhanced. The artistic work praised around the world can not only give the most direct visual enjoyment to people, but also promote people's imagination on the work in the process of appreciation, and make the art smell more dense, and the content represented by the work more colorful. All of these improve the value of art based on people's association.

The specific patterns of manifestation on the design of the platform to enhance the college students' art appreciation capability based on modern information technology are mainly manifested by two major parts: music and dance.

\section{How does the modern technology platform enhance the art appreciation capability}


A certain special area can be set up on the official website of the colleges and universities to provide an exchange platform based on the modern network, so as to enhance the college students' art appreciation capability.

\subsection{Design of "Music Corner"}

Nowadays, Music Appreciation is an important subject for many colleges and universities to enhance the college students' artistic culture. Music Appreciation is an important part in all of public art teaching, which is a necessary approach and effective means for the college students to enhance their art appreciation capability. The establishment of the subject of Music Appreciation and the design of "Music Corner" on the relevant school's official website are helpful for the college students to better cultivate their taste and establish more perfect aesthetics, and cultivate the college students' comprehensive quality.

A lot of songs can be recorded for college students themselves experience, and then let them relyric. Such an independent activity of appreciation and attempt to change can cultivate college students' interest in music appreciation well. Thus college students can constantly experience and create work. In case of obtaining a certain success, college students will have more interest in the music appreciation, and their thought will be more creative and divergent. Similarly, some of the well-known world music can be added in the "Music Corner", attached with hints and narration in a way of text, so that college students can preferably appreciate and understand the beauty of these songs. Some music pieces with national features can be played. The Chinese nation has a long history with many different forms and themes. The unique music pieces and the magical and unique pattern of manifestation of the national instrument since ancient times can let college students have a better understanding of the national music culture, deepen their love for national music, and further deepen their love for motherland. The music pieces performed in "Music Corner" must be in various forms, so that college students can establish a correct standard of review and analysis ability in their mind. Through listening to a wide range of works, it can let college students better appreciate different styles of music and a variety of different emotions and beauty implied in the music. Meanwhile, college students will immerse themselves in the state shaped by music pieces, and share echo of heart, so that their heart will be purified by music. Through the establishment of "Music Corner", it is helpful for college students to develop good aesthetic habits and good aesthetic attitudes towards life, so as to enhance the college students' music appreciation capability.

\subsection{Design of the "Dance Corner"}

This institution of higher learning is one of the important sites to implement dance education. In many fields of art, dance is preferred by many college students with its unique charm and diverse beauty. The corresponding dance learning established in the institution of higher learning can not only reasonably let college students understand the real characteristics of dance, but also enhance their art appreciation capability through the appreciation of dance, and also widen their knowledge, and further strengthen their overall accomplishment.

There are a variety of patterns of manifestation of dance, which are related to social themes describing history and politics in all ages, life themes describing the romance and sentiment between man and man, as well as culture themes describing different nationalities in various countries. The dance practice video with different themes can be provided for college students in the "Dance Corner", so as to let college students understand different periods, different countries, different people and things in different nationalities. Through a variety of dance show, the unique ethnic customs and national culture in the dance can let 
the college students experience diverse kinds of knowledge, and further open up thinking vision of college students step by step. The emotion expressed by dance can not only have a certain positive impact on college students, but also promote them to integrate in the context represented by dance, and sufficiently let college students experience inner and outer beauty. The dance teaching video with different types, categories and styles can be provided for college students in the "Dance Corner", so as to let college students have more understanding of the basic skill of dance, and increase their understanding of basic skill, which is also helpful for their comprehensive development. The dance in a deeper level can express ambition and emotions. The teaching materials provided in the "Dance Corner" also promote the cognitive process of dynamic thinking for the college students to appreciate dance. In the teaching materials provided in the "Dance Corner", it will be more helpful for the college students to understand dance through disintegrating each action of dance and giving detailed physical description and operation source, which is a capability to disintegrate and integrate with the dance possessed by college students. Similarly, it can also promote the formation of the creative thinking mode of college students. To illustrate the principle of dance creation in the "Dance Corner" will stimulate the self-made dance potential of college students, so as to make them better appreciate life. It also provides the college students with an opportunity to upload their own dance, and other college students and teachers can give their comments so as to promote the exchange and better improve the dance level of college students. Similarly, the corresponding knowledge related to selfchoreography is provided in the "Dance Corner" to let college students have a better grasp of the time, power, space and movements of dance, thus enhancing the college students' dance appreciation capability.

\section{Comparison of questionnaire on issues related to art apprecia- tion before and after establishment of platform}

The questionnaire is made for colleges and universities that have provided college students with the platform to enhance the art appreciation capability. The questionnaire conducts a survey at different times based on the same population. A total of 200 questionnaires are distributed, including 187 effective questionnaires. The survey results before and after establishment of platform are shown in Table 1.

As can be seen from the above survey results, the number of people who think that it is necessary to understand the art appreciation knowledge after the establishment of platform which is increased from 45 to 101 , with a total increase amount of $29.95 \%$; compared with no establishment of platform, the number of people who think that it is not necessary is decreased by $31.55 \%$. In the aspect of feelings on the art appreciation, the number of people who feel that the art appreciation is picturesque and interesting after the establishment of platform which is increased by $21.93 \%$. It indicates that the college students' interest in art appreciation after the establishment of platform increases, and the college students gradually like art appreciation through the establishment of platform. In the aspect of what are the learning points in art appreciation, the number of college students who think that it is necessary to learn expertise and cultural connotation after the establishment of platform is respectively decreased by $18.18 \%$ and $12.30 \%$; the number of college students who select the corresponding comprehensive learning is increased by $30.48 \%$. It indicates that the college students who like the art appreciation are gradually developed towards the comprehensive development direction. After the establishment of platform, the number of college students who are willing to discuss the subject of art appreciation with students is increased by $28.88 \%$; in the aspect of willing to talk about their own feelings on the works displayed in the process of art appreciation, the number of college students who select "willing to do" after the establishment of platform is increased by $29.95 \%$. It indicates that after the estab- 
lishment of platform, the college students are more willing to express their own sense of art and their views on art. In the aspect of favor in artistic creation (including calligraphy, sculpture, design, photography, handmade crafts and so on), the number of college students who select "like" is increased by $6.42 \%$; the number of college students who select "dislike" is decreased by $10.16 \%$. It indicates that more college students are more in favor of artistic creation to express their feelings on life. In summary, after the establishment of platform, the college students are fonder of art appreciation, more inclined to the comprehensive learning of art, more brave to express their own sense of art and fonder of artistic creation.

Table 1. Comparison of survey results.

\begin{tabular}{|c|c|c|c|}
\hline Questions & Options & $\begin{array}{l}\text { Selection situation } \\
\text { before establishment } \\
\text { of platform }\end{array}$ & $\begin{array}{l}\text { Selection situation } \\
\text { after establishment } \\
\text { of platform }\end{array}$ \\
\hline \multirow{3}{*}{$\begin{array}{l}\text { Do you think it is necessary to } \\
\text { understand art appreciation } \\
\text { knowledge? }\end{array}$} & Yes & 45 & 101 \\
\hline & No & 112 & 53 \\
\hline & Other answers & 30 & 33 \\
\hline \multirow{2}{*}{ Feelings of Art Appreciation } & Boring content & 109 & 68 \\
\hline & Lively and interesting & 78 & 119 \\
\hline \multirow{3}{*}{$\begin{array}{l}\text { What are the learning points in art } \\
\text { appreciation in your opinion? }\end{array}$} & Expertise of the work & 68 & 34 \\
\hline & $\begin{array}{l}\text { Cultural annotation of } \\
\text { the work }\end{array}$ & 59 & 36 \\
\hline & $\begin{array}{l}\text { The knowledge and } \\
\text { content are equally } \\
\text { important }\end{array}$ & 60 & 117 \\
\hline \multirow{3}{*}{$\begin{array}{l}\text { Do you like to discuss the subject } \\
\text { of art appreciation with the } \\
\text { students? }\end{array}$} & Like & 35 & 89 \\
\hline & Dislike & 56 & 40 \\
\hline & General & 96 & 59 \\
\hline \multirow{2}{*}{$\begin{array}{l}\text { Are you willing to talk about your } \\
\text { feelings on the work displayed in } \\
\text { the process of art appreciation? }\end{array}$} & Yes & 86 & 142 \\
\hline & No & 101 & 45 \\
\hline \multirow{3}{*}{$\begin{array}{l}\text { Do you like artistic creation } \\
\text { (including calligraphy, sculpture, } \\
\text { design, photography, handmade } \\
\text { crafts and so on)? }\end{array}$} & Like & 86 & 98 \\
\hline & Dislike & 52 & 33 \\
\hline & General & 49 & 56 \\
\hline
\end{tabular}

\section{Conclusion}

Through the promotion based on the modern information technology, that is, the promotion of special column platform of colleges and universities, it can better cultivate college students' art appreciation capability. In other words it is extremely necessary to cultivate the college students' art appreciation capability. To possess corresponding art appreciation capability will be a good safeguard for the college students to lead a high-quality life in the future. It's just like an old saying, "only the fittest survives." Under such a great atmosphere, it does not exist solely because of certain individuals, but each takes what one needs. However, the gradual maturity and continuous improvement of this modern information technology platform is an endless driving force for college students to enhance the art appreciation capability.

\section{References}

1. Xiao Xuejian, Li Tian. 2008. On culture of college students' art appreciation capability. Education Research Monthly, (9): 95. 
2. Bai Xue. 2012. How to improve music accomplishment. Entrepreneur World: Journal of Middle Month, (6): 116-116.

3. Benno Belke, Helmut Leder, M. Dorothee Augustin, et al. 2006. Mastering style Effects of explicit style-related information, art knowledge and affective state on appreciation of abstract paintings. Psychology Science, 48 (2).

4. Lixia Shen. 2012. Investigation and application on appreciation methods of art among students in comprehensive colleges and universities[C].//Frontiers in Computer Education. pp: 341-345.

5. Liu Juan. 2012. Researching about teaching strategies of current college art appreciation courses[C].//Proceedings of 2012 International Symposium - Educational Research and Educational Technology. pp: 220-224.

6. Janja CRCINOVIC ROZMAN, Matjaz DUH. 2010. Connecting chosen music and artworks[C].//Information Modeling and Knowledge Bases XXI. pp: 370-378.

7. Owen, G.S., Szmukler, G., Richardson, G. et al. 2013. Decision-making capability for treatment in psychiatric and medical in-patients: Cross-sectional, comparative study. The British Journal of Psychiatry: The Journal of Mental Science, 203(6): 461-467.

8. Christine Zakzewski. 2012. Teaching the media and information technology major an introduction to engineering of modern communication systems. Journal of Systemics, Cybernetics and Informatics, 4(6). 